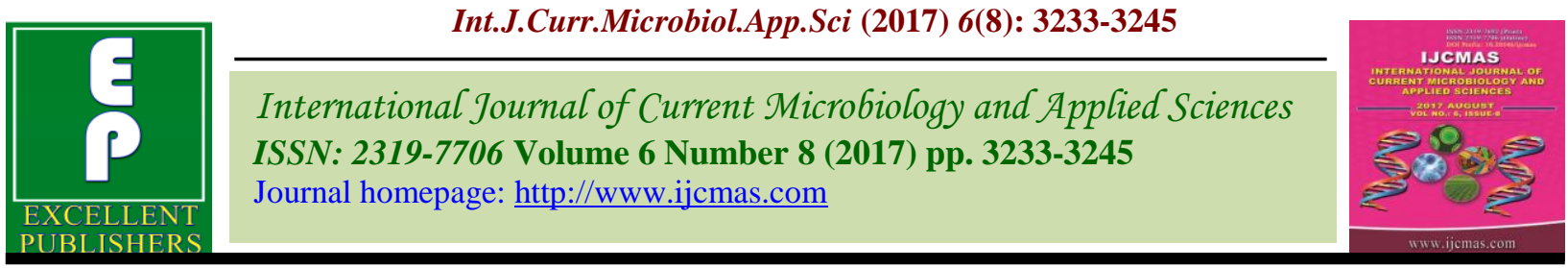

Original Research Article

https://doi.org/10.20546/ijcmas.2017.608.386

\title{
Fresh Farm Vegetables as a Source of Virulent Drug Resistant Salmonella enterica
}

\author{
B. Sood ${ }^{1 *}$, P. Sahota ${ }^{1}$ and M. Hunjan ${ }^{2}$ \\ ${ }^{1}$ Department of Microbiology, ${ }^{2}$ Department of Plant Pathology, Punjab \\ Agricultural University, Ludhiana-141004, India \\ *Corresponding author
}

\section{A B S T R A C T}

\begin{tabular}{|l|}
\hline Ke y w or d s \\
MAR, Salmonella \\
enterica, \\
Coliforms, \\
Village field, \\
Virulence genes. \\
\hline Article Info \\
\hline $\begin{array}{l}\text { Accepted: } \\
\text { 26 June } 2017 \\
\text { Available Online: } \\
\text { 10 August } 2017\end{array}$ \\
\hline
\end{tabular}

Plants are well known as vectors for transmission of human enteric pathogens and exaggerate the outbreak events. Salmonella enterica, rod shaped, facultative anaerobic bacteria interferes with the microbial safety of raw vegetables. This study explored three sources: Village fields, Supermarkets and Street Vendors to ensure the microbial risk among seven raw vegetables $(\mathrm{N}=725)$. Water samples of the hand pumps sourced from village fields showed total coliforms $>10 \mathrm{ml}^{-1}(75.6-98.5 \%)$ and faecal coliforms $>10 \mathrm{ml}^{-1}$ (59.6-91.2\%). The highest Aerobic Mesophilic count (6.66 $\operatorname{log~cfu~g}^{-1}$ ) in spinach samples and highest Salmonella enterica count (5.09 $\left.\log \mathrm{cfu} \mathrm{g}^{-1}\right)$ in tomato samples procured from vendors was observed. Resistance to Lyncosamides, Tetracycline, Imipenem, Metronidazole and Cloxacillin has been observed. Twenty isolates were found in high Multiple Antibiotic Resistance (MAR) index range 0.36-0.8. Polymerase Chain Reaction (PCR) analysis has revealed the presence of sipB (100\%), sopB (100\%), spiA (100\%), invA $(100 \%)$ except hilA gene which was found absent in all isolates. The in-vivo expression of these virulence genes and resistance to multiple antimicrobials can potentially threat the healthy being of consumers.

\section{Introduction}

Salmonellosis is a disease caused by Salmonella spp. which governs its transmission through contaminated water, vegetables, meat and meat products (Schleker et al., 2015).

Salmonella was reported to be present in lettuce, spinach, tomato, radish (De oliveira et al., 2011; Sant'Ana et al., 2012). Recent multistate outbreak of Salmonella infection was declared by CDC in 2015 affecting a total of 907 persons. According to CDC 2016 report, Salmonella contaminated cucumbers imported from Mexico were the likely source of outbreak. Belonging to Enterobacteriacea family, Salmonella is well known for its intracellular nature. The recognition that the Salmonella enterica serovar typhi is host adapted pathogen is well established (Gopinath et al., 2012). The plant edible regions and resident epiphytic bacteria harbour the colonization of Salmonella during stress and increase its fitness (Guo et al., 2001; Delbeke et al., 2015; Potnis et al., 2015).

Epidemiological studies have shown that India has increased number of Multi Drug Resistant (MDR) Salmonella strains (Ochiai et al., 2008). Resistance to traditional 
antibiotics like ampicillin, chloramphenicol and trimethoprim-sulfamethoxazole (Sood et al.,1999) against salmonella infections has led to switching for new antibiotics like fluoroquinolones and cephalosporins which are also being ineffective (Hasan et al., 2008).

The targeting of virulence genes in the indigenous isolates of Salmonella may reflect the risk of illness channelled through raw consumption of vegetables. Various chromosomal species specific virulence gene such as invA, hilA, sipA, $\operatorname{sip} B$ and $\operatorname{sop} B$ are important elements in pathogenesis. The protein InvA is essential for epithelial invasion (Galán and Curtiss, 1990). The hilA gene product regulates the expression of invasion genes encoded on Salmonella pathogenicity island 1 (SPI1) and is important virulence determinant in Salmonella pathogenesis (Bajaj et al., 1996). Salmonella invasion protein SipA aids the internalization of bacteria by binding and polymerising the host actin (Lilic et al., 2003). Cell invasion protein SipB is required for cell to enter in host plasma membrane and induction of apoptosis by activating caspase-1 (Hersh et al., 1999). Salmonella virulence mechanism involves delivery of effector protein sopB (inositol polyphosphate phophastase) that act into the host cytoplasm through type III secretion system (Galan and Zhou, 2000).

According to the regulations laid by Bureau of Indian Standard IS (5887:1999) for Salmonella, absence in 25gram of food sample is mandatory to keep it safe.

The present study focussed on the phenotypic profile based on biochemical and antibiotic susceptibility of indigenous Salmonella enterica isolates from fresh vegetables from three sources and distribution of its virulence genes so as to put forward proper sanitation strategy to obstruct the spread of food borne illness.

\section{Materials and Methods}

\section{Study area and sampling}

The Buddha Nallah, a natural stream of Sutlej, traversing through Ludhiana city of Punjab state has high Total Dissolved solids $>1000 \mathrm{mg} / \mathrm{L}$, chlorides up to $400 \mathrm{mg} / \mathrm{L}$, Chemical Oxygen Demand $>400 \mathrm{mg} / \mathrm{L}$, Biochemical Oxygen Demand 52-195 mg/L, Most Potable Number upto $2400+$ per $100 \mathrm{ml}$. Villages along the Buddha Nallah are known for vegetables growers. They use irrigation pumps, river or streams for cultivation. Epidemiological surveillance study for the microbiological quality of fresh vegetables was routinely carried out during the vegetable of the season for the period of $2^{1 / 2}$ years (July 2013-December 2015).Water samples from the irrigation pumps were collected according to the standard method of BIS (IS10500:1991).

A total of 420 samples of salad vegetables such as carrot, radish, cucumber, tomato, cabbage, spinach and long melon were procured from village fields along Buddha Nallah. In comparison, 75 samples from supermarkets and 230 samples from street vendors were also collected.

\section{Enumeration of Salmonella enterica}

The fresh vegetable, 25grams of sample was taken and washed with autoclaved water so as to omit any environmental contamination. Vegetable sample was chopped with the help of sterile knife into $2-3 \mathrm{~cm}$ pieces and transferred to the $225 \mathrm{ml}$ water blank. It was shaken vigorously for uniformity and serial dilutions of the suspension were spread onto Salmonella-Shigella Agar Base (HiMedia Laboratories Pvt. Ltd., Mumbai) IS (5887:1999) plates in triplicates for each dilution and incubated at $37^{\circ} \mathrm{C}$ for $24-48$ hours. Following incubation, all colonies on 
dishes containing 30-300 colonies were counted per dilution and $\log \mathrm{cfu}^{-1}$ was calculated. The presumed colonies were verified by complete phenotypic characterisation.

\section{Phenotypic characterization}

The isolates were verified as Salmonella spp. by their size, shape, Gram's staining, simple staining, motility and colony morphology, biochemical tests, virulence based tests and further confirmed with molecular method. Antibiotic susceptibility was also evaluated using the Kirby-Bauer disc diffusion method on Mueller Hinton agar with 25 antibiotics belonging to 15 different classes; $\beta$-Lactams, Fluoroquinolones, Aminoglycoside, $1^{\text {st }}$ Generation Cephalosporins, $2^{\text {nd }}$ Generation Cephalosporins, $\quad 3^{\text {rd }} \quad$ Generation Cephalosporins, Chloramphenicol, Tetracycline, Metronidazole, Macrolide, Sulphonamides, Lyncosamides, Glycopeptides, Nitrofurans and Carbapenems.

\section{Bacterial genome extraction}

Genomic DNA was extracted from colonies that were identified as Salmonella enterica with the help of Invitrogen Easy DNA® Isolation Kit (Invitrogen Inc.) as per the manufacturer's protocol from selected bacterial strains grown in nutrient broth for overnight at optimal temperature. DNA was eluted into $100 \mu \mathrm{l} 1 \mathrm{X}$ TE buffer (Invitrogen Inc.). Quantity and quality of DNA was checked on TECAN 2000 Nanoquant Plate.

The DNA of all the samples was diluted to $25 \mathrm{ng} / \mu \mathrm{l}$ by adding nuclease free water and stored at $-20^{\circ} \mathrm{C}$. Alternatively, DNA quality was checked on $0.8 \%$ agarose gel. A single sharp band of DNA signified high quality of DNA. DNA of each sample was diluted to 25ng per $\mu \mathrm{l}$ of nuclease free water (Promega Inc.) before the PCR assay.

\section{PCR assay}

Uniplex PCR was performed with reaction volume of $30 \mu \mathrm{l}$ for each sample, that contained $1.5 \mathrm{mM}$ of $25 \mathrm{mM} \mathrm{Mgcl} 2$ (Promega Inc.), $1 X$ Go Taq TM buffer (Promega Inc.), $0.2 \mathrm{mM}$ of dNTPs (Promega Inc.), $0.5 \mu \mathrm{M}$ of each primers (Table 1), 2U of GoTaqTM DNA polymerase (Promega Inc.) and $50 \mathrm{ng} / \mu \mathrm{l}$ of the DNA template. The final volume of the reaction was adjusted with Nuclease free Water (Promega Inc.).The PCR conditions consisted of a pre-incubation step for $5 \mathrm{~min}$ at $94^{\circ} \mathrm{C}, 35$ cycles of denaturation at $94^{\circ} \mathrm{C}$ for 30 sec, annealing step for $30 \mathrm{sec}$ (Table 1) with extention time of $40 \mathrm{sec}$ at $72^{\circ} \mathrm{C}$ and a termination step with a final extension for $7 \mathrm{~min}$ at $72^{\circ} \mathrm{C}$.

After amplification, the product was loaded onto the $1.5 \%$ agarose gel, visualized under UV light and photographed using SYNGENE gel documentation system with Gene snap software programme.

\section{Results and Discussion}

\section{MPN index of irrigation water}

Water for irrigation has utilized faecal coliform as an indicator of acceptable quality. It was observed that all vegetable samples growing areas (village fields) around Buddha nallah have contaminated ground water with high MPN index of $>10 / \mathrm{ml}(1000 / 100 \mathrm{ml})$ with highest positive percentage of 98.5 and 91.2 for cucumber and spinach respectively (Table 2). This value is above the desirable limit $(1,000 \mathrm{MPN} / 100 \mathrm{ml}$ as recommended Indian environment ministry) and undesirable for irrigation purpose.

Water can predispose the coliform to the fields if the ground water is mixed with the sewage, runoff water in from immediate vicinity of livestock and use of untreated 
manure into the fields. Owing to dissemination of pathogens into the field, greater risk may establish which aids reaching the pathogens to their threshold of virulence with increase in nutrient abundance.

\section{Aerobic Mesophilic Count (AMC) of vegetables}

AMC per gram for each vegetable among three sources showed no significant difference $(\mathrm{P}>0.05)$ in mean log cfu value (Table 2). Among three sources, the mean AMC for spinach was in range of 6.25-6.66 log $\mathrm{cfu} \mathrm{g}^{-1}$, tomato 4.51-5.71log $\mathrm{cfu} \mathrm{g}^{-1}$, carrot 4.94-5.84 $\log$ cfu $\mathrm{g}^{-1}$, Radish 4.8-5.75 log cfu $\mathrm{g}^{-1}$, Cucumber 5.15-5.92 log cfu $\mathrm{g}^{-1}$, cabbage 4.07-5.24 log cfu g ${ }^{-1}$ and Long melon 4.96-6 $\log \mathrm{cfu} \mathrm{g}^{-1}$ (Table 2). Similar to the findings of the present study, aerobic plate count of raw vegetables were evaluated to be in range of 5-10 log cfu $\mathrm{g}^{-1}$ (Viswanathan and Kaur, 2001; Saddik et al., 1985; Aycicek et al., 2006; Jeddi et al., 2014).

The highest count on spinach phyllosphere was due to its leafy structure, leaf features such as glandular trichomes and stomata where bacteria aggregate and propagate in the ambient temperature conditions $\left(25-35^{\circ} \mathrm{C}\right)$. AMC is considered indispensible microbiological indicators for food quality as it reflects the exposure of the sample to any contamination, and, in general, the existence of favourable conditions for the multiplication of microorganisms. In our study, the AMC of all the vegetables from street vendors has mean count lower than previously reported by Viswanathan and Kaur (2001). This might be due to the fact that the washing of raw vegetable prior to microbiological analysis has eliminated the effect of bacteria in soil which is attached to the phyllosphere.

Among different sources, the highest AMC was found in vegetables from vendor whereas lowest count was of vegetables procured from supermarkets (Table 2). Seo et al., (2010) reported AMC ranged between 2.0-9.7log cfu $\mathrm{g}^{-1}$ in 345 minimally processed vegetables from department store, supermarket, and restaurant. Carrot samples procured from wholesalers and retail stores had found with total plate count of $3.8-6.5 \log \mathrm{cfu} \mathrm{g}^{-1}$ and $7.8 \log \mathrm{cfu} \mathrm{g}^{-1}$ (Aycicek et al., 2006; Abadias et al., 2008). Mean AMC of supermarket vegetables (Table 2) was observed in agreement with Cardamone et al., (2015) and Aycicek et al., (2006). The lower AMC of supermarket vegetables as compared to village fields and vendors was due to the thorough washing of the vegetables and storage at low temperature. However, prolonged storage and inherent quality of the vegetable are the other determinants of microbial spoilage.

On comparison of village field samples with those which were vending, no significant value observed and it implies to the fact that majority of the vendors purchase vegetables from the nearby village fields from where easy marketing with low freight is possible.

This leads to the circulation of same microbial quality product throughout city and made negligible or little change due to poor handling and improper sanitation.

\section{Occurrence of Salmonella enterica}

Out of 420 vegetable samples collected from village fields, 243 (57.90\%) were positive for Salmonella enterica which was higher than its percent occurrence in supermarket samples $(38 / 75,50.12 \%)$. The percent contamination increased to $73.48 \%$ in vendor samples.

Cucumber samples from vendors had shown highest percent contamination by Salmonella enterica $(82.85 \%)$ followed by $66.66 \%$ in case of tomato and $78.12 \%$ in cucumber from 
village fields (Fig. 1). Results in this study completely contradict $1.3 \%$ and $3.3 \%$ occurrence observed by Abadias et al., (2008) and García-Villanova et al., (1987) in fresh produce. Comparable percentage prevalence of Salmonella was observed by Salleh et al., (2003) in vegetable samples.

The high incidence may attribute to environmental contamination sourced from animal manure applied to the fields, contaminated water used for irrigation, postharvest poor handling of the vegetables and improper storage conditions.

The samples with vendors had shown even highest rate of Salmonella which might be due to the additive effect of constant sprinkling of the contaminated water over the vegetables for retaining their freshness. The high predisposition of pathogen into the vegetables after harvesting should be avoided and critical decontamination approaches should be adopted.

All vegetables samples tested were found to have $>4 \log \mathrm{cfu} \mathrm{g}^{-1}$ mean count. Count from village field samples range from $4.32 \mathrm{log}$ cfu $\mathrm{g}^{-1}$ in spinach to $4.97 \log \mathrm{cfu} \mathrm{g}^{-1}$ in carrot (Table 2).

Supermarket samples were also found to effect the growth of Salmonella enterica with mean count range of $4.02 \mathrm{log} \mathrm{cfu} \mathrm{g}^{-1}$ in long melon to $4.61 \log$ cfu g $^{-1}$.

Among all vegetable samples, Salmonella enterica count was highest recorded in tomato samples collected from street vendors (Table 2 ). The contamination is mainly through root uptake system and through natural openings on plant surfaces. Salmonella thrive better in the stem scar and cracks in tomato and their survival rates make the inactivation of the internalized pathogen more challenging (Cummings et al., 2001).

Mean count of $S$. enterica in carrot, radish, tomato, cucumber and spinach among the village fields and street vendor differ significantly from supermarket samples $(\mathrm{p}<0.05)$. The low count of Salmonella in supermarket vegetables as compared to village fields and vendors was due to the thorough washing of the vegetables and storage at low temperature. However, prolonged storage and inherent quality of the vegetable are the other determinants of microbial spoilage.

The organic agricultural practises in India emphasize on the use of animal manure to the fields which can be a factor of introduction of food linked pathogens. Pre-treatment of this fertilizer prior to employment should be critically considered.

Table.1 List of primers used for targeting species specific virulent genes of Salmonella enterica

\begin{tabular}{|l|l|l|l|l|}
\hline Gene & Primer sequence $\left(\mathbf{5}^{\prime} \rightarrow \mathbf{3}^{\prime}\right)$ & $\begin{array}{l}\text { Product } \\
\text { size (bp) }\end{array}$ & $\begin{array}{l}\text { Annealing } \\
\text { temp. }\end{array}$ & Reference \\
\hline invA & $\begin{array}{l}\text { F-GCCTGCCGGAAGTATTGTTA } \\
R-A C C G C C A G A C A G T G G T A A A G\end{array}$ & 280 & $54.5^{\circ} \mathrm{C}$ & $\begin{array}{l}\text { Suo et al., } \\
2010\end{array}$ \\
\hline hilA & $\begin{array}{l}F-A T T G C C G A G A A A A T G T G G A A \\
\text { R-TCAGCCCATGCCGTATTTAT }\end{array}$ & 169 & $52^{\circ} \mathrm{C}$ & $-d o-$ \\
\hline Spi A & $\begin{array}{l}\text { F-CCAGGGGTCGTTAGTGTATTGCGTGAGATG } \\
\text { R-CGCGTAACAAAGAACCCGTAGTGATGGATT }\end{array}$ & 550 & $66.5^{\circ} \mathrm{C}$ & $\begin{array}{l}\text { El-Allaoui et } \\
\text { al., } 2013\end{array}$ \\
\hline Sip B & $\begin{array}{l}\text { F-GGACGCCGCCCGGGAAAAACTCTC } \\
\text { R-ACACTCCCGTCGCCGCCTTCACAA }\end{array}$ & 875 & $66.5^{\circ} \mathrm{C}$ & $-d o-$ \\
\hline Sop B & $\begin{array}{l}\text { F-CGGACCGGCCAGCAACAAAACAAGAAGAAG } \\
\text { R-TAGTGATGCCCGTTATGCGTGAGTGTATT }\end{array}$ & 220 & $66.5^{\circ} \mathrm{C}$ & $-d o-$ \\
\hline
\end{tabular}


Table.2 Microbiological analysis of raw vegetables collected from three source

\begin{tabular}{|c|c|c|c|c|c|}
\hline Vegetables & Source & $\begin{array}{c}\text { Total coliforms }^{\mathrm{b}} \\
>10 / \mathrm{ml}\end{array}$ & $\begin{array}{c}\text { Faecal coliforms }^{\mathrm{b}} \\
>\mathbf{1 0} / \mathbf{m l}\end{array}$ & $\begin{array}{c}\text { Mean AMC } \\
\left.\text { cfu g }^{-1}\right)\end{array}$ & $\begin{array}{l}\text { Salmonella enterica } \\
\text { count }^{\mathrm{a}}\left(\log \text { cfu }^{-1}\right)\end{array}$ \\
\hline \multirow[t]{3}{*}{ Carrot } & Village field & 90.1 & 68.1 & $5.55^{\mathrm{d}}$ & $4.97^{\mathrm{k}}$ \\
\hline & Supermarket & ND & ND & $4.94^{\mathrm{d}}$ & $4.54^{1}$ \\
\hline & Street vendors & ND & ND & $5.84^{\mathrm{d}}$ & $4.83^{\mathrm{k}}$ \\
\hline \multirow[t]{3}{*}{ Radish } & Village field & 86.5 & 70.1 & $5.44^{\mathrm{e}}$ & $4.77^{\mathrm{m}}$ \\
\hline & Supermarket & ND & ND & $4.8^{\mathrm{e}}$ & $4.38^{\mathrm{n}}$ \\
\hline & Street vendors & ND & ND & $5.75^{\mathrm{e}}$ & $4.72^{\mathrm{m}}$ \\
\hline \multirow[t]{3}{*}{ Cucumber } & Village field & 98.5 & 74.6 & $5.92^{\mathrm{f}}$ & $4.60^{\circ}$ \\
\hline & Supermarket & ND & ND & $5.76^{\mathrm{f}}$ & $4.07^{\mathrm{p}}$ \\
\hline & Street vendors & ND & ND & $5.15^{\mathrm{f}}$ & $4.51^{\circ}$ \\
\hline \multirow[t]{3}{*}{ Tomato } & Village field & 75.6 & 64.9 & $5.71^{\mathrm{g}}$ & $4.95^{\mathrm{q}}$ \\
\hline & Supermarket & ND & ND & $4.51^{\mathrm{g}}$ & $4.61^{\mathrm{r}}$ \\
\hline & Street vendors & ND & ND & $5.51^{\mathrm{g}}$ & $5.09^{\mathrm{q}}$ \\
\hline \multirow{3}{*}{ Cabbage } & Village field & 86.5 & 59.6 & $5.24^{\mathrm{h}}$ & $4.54^{\mathrm{s}}$ \\
\hline & Supermarket & ND & ND & $4.07^{\mathrm{h}}$ & $4.08^{\mathrm{s}}$ \\
\hline & Street vendors & ND & ND & $5.15^{\mathrm{h}}$ & $4.32^{\mathrm{s}}$ \\
\hline \multirow[t]{3}{*}{ Spinach } & Village field & 96 & 91.2 & $6.65^{\mathrm{i}}$ & $4.32^{\mathrm{t}}$ \\
\hline & Supermarket & ND & ND & $6.25^{\mathrm{i}}$ & $4.07^{\mathrm{u}}$ \\
\hline & Street vendors & ND & ND & $6.66^{\mathrm{i}}$ & $4.44^{\mathrm{t}}$ \\
\hline \multirow{3}{*}{ Long melon } & Village field & 98.3 & 79 & $5.55^{\mathrm{j}}$ & $4.35^{\mathrm{v}}$ \\
\hline & Supermarket & ND & ND & $4.96^{\mathrm{j}}$ & $4.02^{\mathrm{v}}$ \\
\hline & Street vendors & ND & ND & $6^{\mathrm{j}}$ & $4.23^{\mathrm{v}}$ \\
\hline
\end{tabular}

a- level of significance at $\mathrm{p}<0.05$

b- Desirable limit is $10 / \mathrm{ml}$

$\mathrm{ND}=$ Not Determined (low $\mathrm{pH}$ of Tomato gives false positive results, true representative of water sample for vegetables washing could not be produced)

Table.3 Multiple Antibiotic Resistance (MAR index) pattern for Salmonella spp. Isolates

\begin{tabular}{|l|c|}
\hline Isolates & Multiple Antibiotic Resistance Index \\
\hline LM INT 25 & 0.6 \\
\hline CU INT 64 & 0.6 \\
\hline CB INT 45 & 0.72 \\
\hline CR EXT 8 & 0.68 \\
\hline TO 34 & 0.68 \\
\hline CU EXT 6 & 0.68 \\
\hline SP 44 & 0.68 \\
\hline CR INT 25 & 0.72 \\
\hline TO 57 & 0.72 \\
\hline LM EXT 5 & 0.64 \\
\hline RA INT 22 & 0.64 \\
\hline SP 31 & 0.72 \\
\hline RA INT 58 & 0.72 \\
\hline CU EXT 44 & 0.72 \\
\hline RA EXT 10 & 0.72 \\
\hline SP 6 & 0.8 \\
\hline TO 21 & 0.8 \\
\hline CB EXT 18 & 0.52 \\
\hline RA EXT 37 & 0.52 \\
\hline MTCC 773 & 0.36 \\
\hline
\end{tabular}


Fig.1 Percentage occurrence of S. enterica in vegetables among three sources

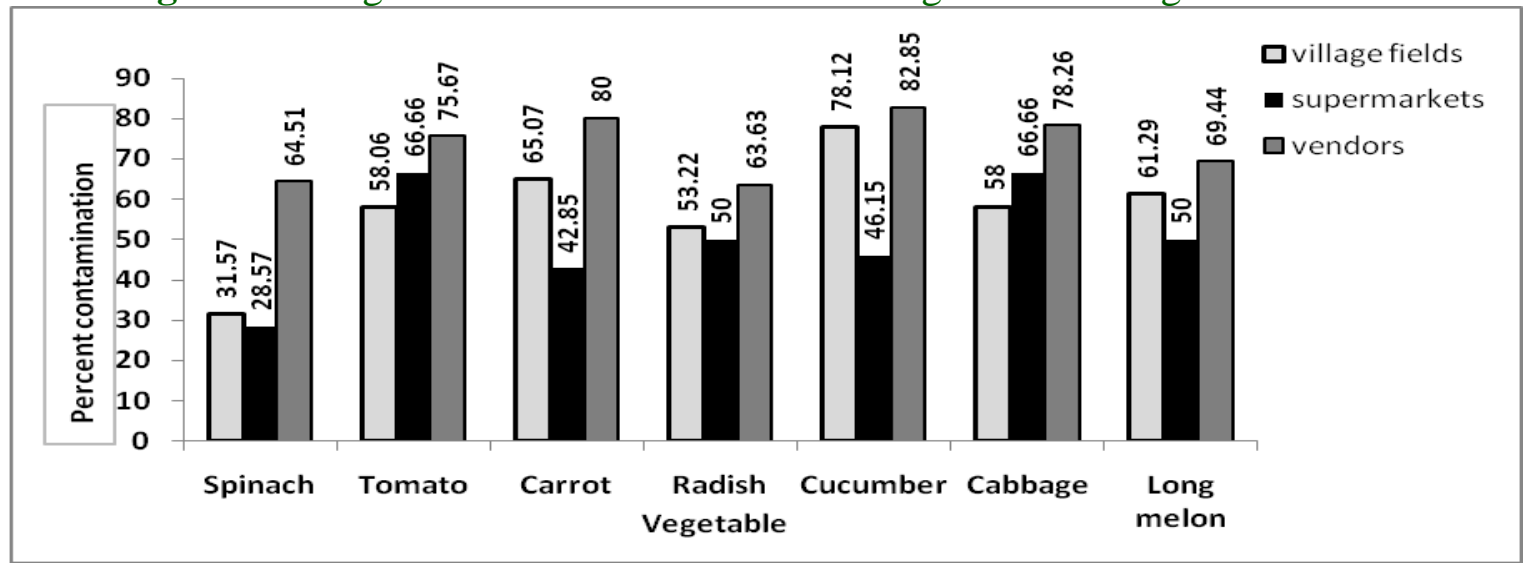

Fig.2 Percent frequency of antibiotic resistance exhibited by Salmonella spp. isolates

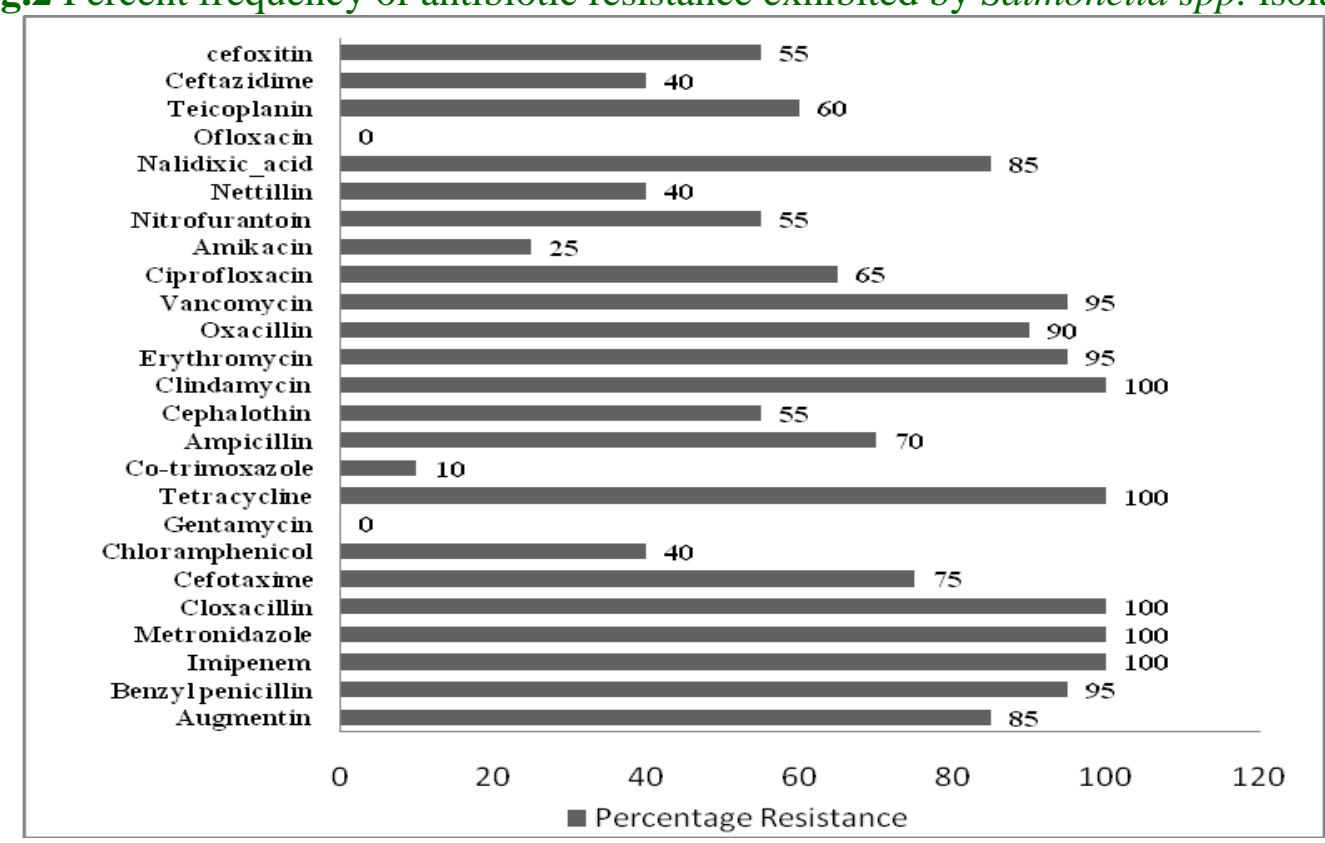

Fig.3 Agarose gel electrophoresis of PCR products from representative Salmonella enterica isolates. M lane stands for the molecular weight standard: 1kbp ladder (Invitrogen). Lanes 1-5 contains products of $S$. enterica isolates showing the $16 \mathrm{~S}$ rDNA (312bp fragment) along with positive control of $S$. enterica MTCC 733

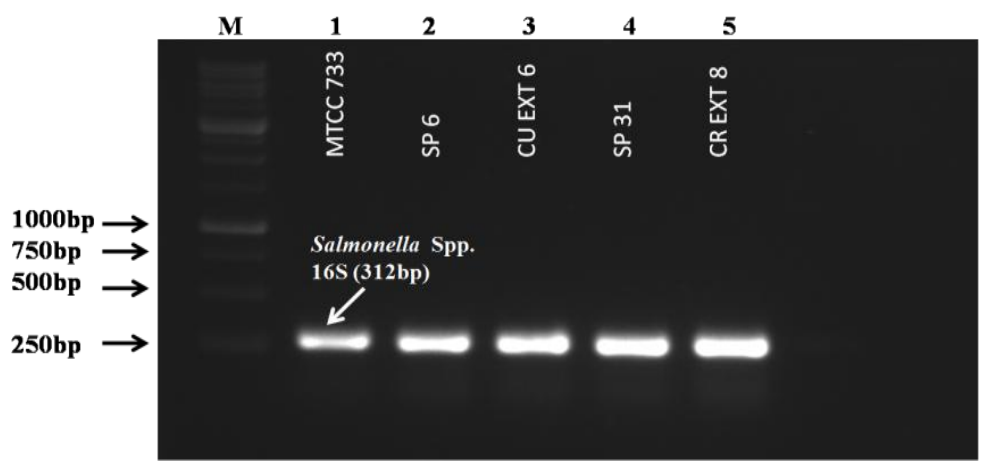


Fig.4 Agarose gel electrophoresis of PCR products from representative Salmonella enterica isolates. M lane stands for the molecular weight standard: 1kbp ladder (Invitrogen). Lanes 1-14 contains products of $S$. enterica isolates showing the $\operatorname{sip} B$ gene (875bp fragment) along with positive control of $S$. enterica MTCC 733

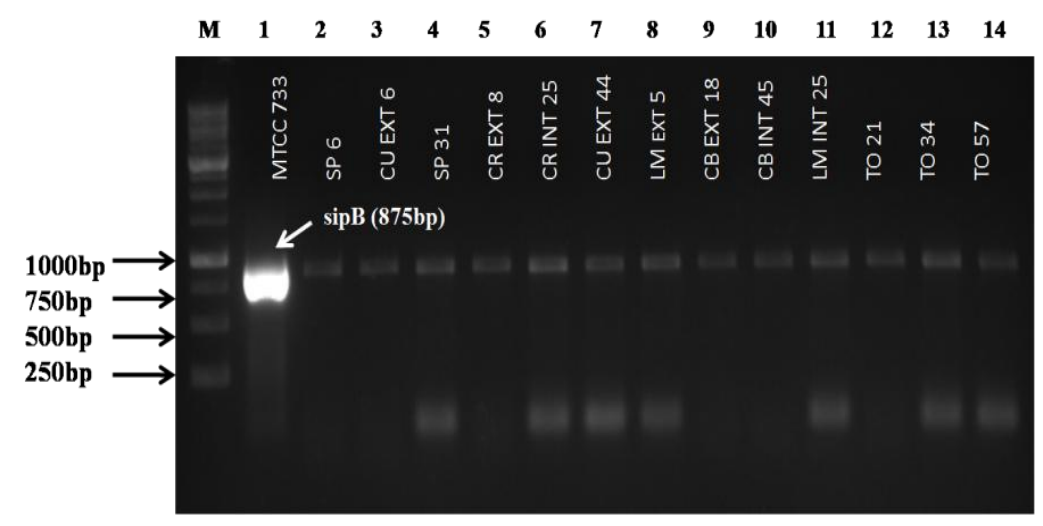

Fig.5 Agarose gel electrophoresis of PCR products from representative Salmonella enterica isolates. M lane stands for the molecular weight standard: 100bp ladder (Invitrogen). Lanes 1-16 contains products of $S$. enterica isolates showing the $s o p B$ gene (220bp fragment) along with positive control of $S$. enterica MTCC 733

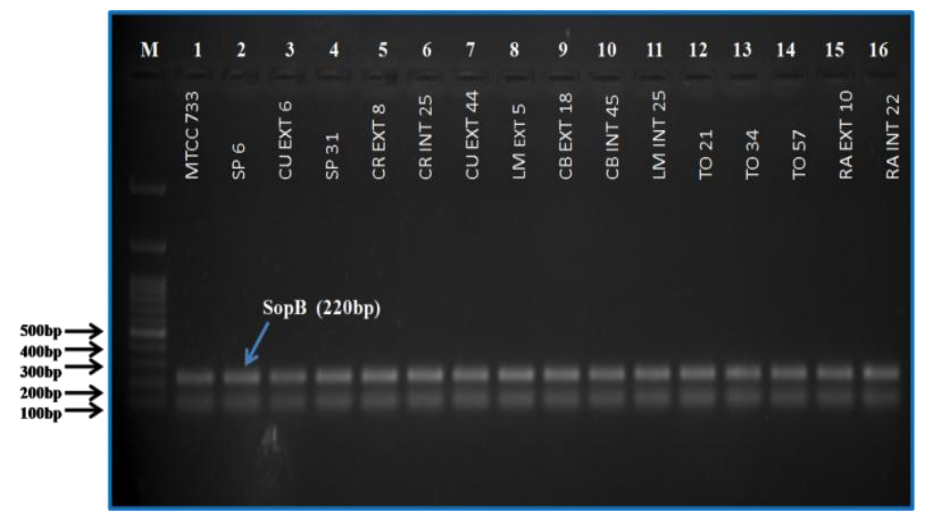

Fig.6 Agarose gel electrophoresis of PCR products from representative Salmonella enterica isolates. M lane stands for the molecular weight standard: 1kbp ladder (Invitrogen). Lanes 1-14 contains products of $S$. enterica isolates showing the spiA gene (550bp fragment) along with positive control of S. enterica MTCC 733

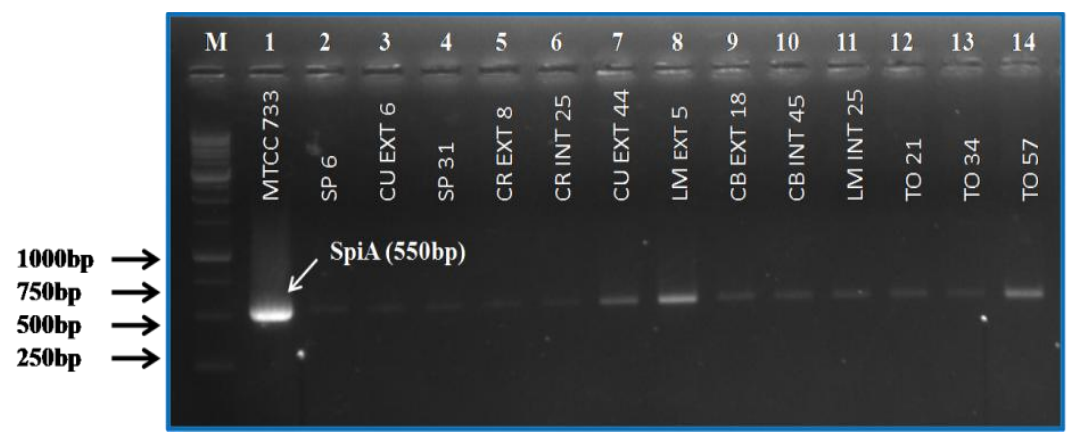


Fig.7 Agarose gel electrophoresis of PCR products from representative Salmonella enterica isolates. M lane stands for the molecular weight standard: 1kbp ladder (Invitrogen). Lanes 1-14 contains products of $S$. enterica isolates showing the invA gene (280bp fragment) along with positive control of $S$. enterica MTCC 733

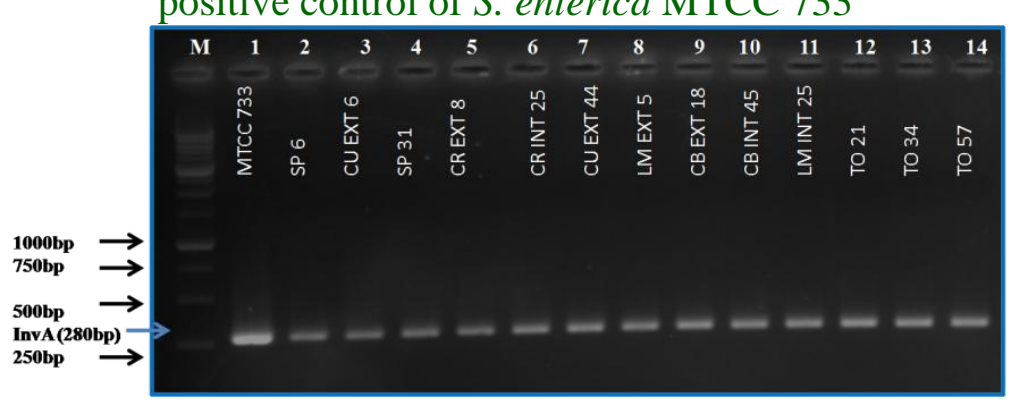

Phenotypic characteristics of $S$. enterica isolates

Strains of Salmonella spp. isolated from vegetables were biochemically characterised and found that all the isolates were motile, majority non-haemolytic, $\mathrm{H}_{2} \mathrm{~S}$ producers, glucose fermenters but could not ferment lactose, sorbitol, xylose, rhamnose, raffinose and adonitol (data not shown).

Clindamycin (2mcg), Tetracycline $(30 \mathrm{mcg})$, Metronidazole (5mcg), Imepenem $(10 \mathrm{mcg})$ and Cloxacillin (5mcg) had shown 100\% resistance to vegetable isolates of Salmonella spp. These isolates have high level of resistance to penicillin (95\%), Augmentin (30 mcg) (85\%), Vancomycin (30 mcg) (95\%), Oxacillin (1 mcg) (90\%), Erythromycin (15 $\mathrm{mcg})(95 \%)$ and Nalidixic Acid $(30 \mathrm{mcg})$ (85\%) (Fig. 2).

Salmonella enteritidis and Salmonella typhimurium isolates obtained from the raw vegetables (ulam) were found to exhibit high resistance against ampicillin (100\%), erythromycin (100\%), amoxicillin/clavunic acid (81.3\%), cephalothin (75\%), streptomycin $(50 \%)$ and ciprofloxacin $(50 \%)$ (Najwa et al., 2015). Other studies have found a certain level of tolerance in Salmonella strains against nalidixic acid, ciprofloxacin, chromaphenicol, co-trimoxazole, ampicillin, gentamycin, augmentin and amoxicillin
(Chaudhary et al., 2013; Adeshina et al., 2012). The resistance pattern quite similar in our study has proved the indiscriminate use of antibiotics whose further practise may lead to complete resistance to tested antibiotics.

Scallan et al., (2011) reported that more than $90 \%$ of the foodborne infections worldwide are due to Salmonella infections. These isolates may potentially transmit their virulence factors and cause human infections. The virulence and MDR of these isolates directly reflects the substantial contamination water of Buddah Nallah used for irrigation purpose or else its percolation to the soil that is used for cropping. The high incidence of Salmonella in vegetables and control of this spread of resistance needs attention and effection empirical therapy should be instituted.

The high MAR index range of 0.36-0.8 for Salmonella spp. isolated from fresh vegetables has been observed and could pose a serious health risk to the consumers when infectivity reaches a certain threshold (Table $3)$.

High MAR index recorded in the study has found in complete agreement with those discussed by Adeshina et al., (2012) and Najwa et al., (2015) in which Salmonella strains from raw salad vegetables had found with MAR index range of 0.27 to 0.82 . 
The detection of Salmonella is an indication of contamination of sewage of human origin, which was most detected in the study was also observed to be most resistant and hence implies human use/misuse of antibiotics. Although, it is possible that isolates may have acquired the genes for resistance to multiple antibiotics from other enteric bacteria.

\section{Molecular detection of Salmonella enterica and its virulence gene distribution}

All the 20 Salmonella strains (isolated and MTCC 733) were identified with 16S rDNA PCR assay and subsequent electrophoresis generated 312bp gene fragment (Fig. 3).

The 16S rDNA and 16S-23S rDNA internal transcribed spacer (ITS) region have been the most popular target for bacterial taxonomy. Furthermore, the ITS sequences of Salmonella serovars might be useful for analysis of the phylogenetic tree for Salmonella serovars.

Present study had also illustrated that all the Salmonella isolates were positive for $\operatorname{sip} B$ of 875bp (Fig. 4), sopB of 220bp (Fig. 5), spiA of 550bp (Fig. 6) and invA of 280bp gene fragment (Fig. 7) whereas none of the strain was positive for hilA (169bp).

These genes were also screened by other researchers in meat, poultry and food samples (El Allaoui et al., 2013; Karmi, 2013; Rowlands et al., 2014) which are in substantial agreement with our findings.

International Standard procedure for detection of Salmonella targets invasion gene invA, whose presence in our isolates has, confirmed its potential virulence (Amini et al., 2010). The invA gene which is responsible for invasion of cells, have the capacity to invade and survive in macrophages (Gole et al., 2013). Presence of virulence genes such as
spiA, $s o p B$ and $\operatorname{sip} B$ required for effective colonization and survival in host cell has been observed which corroborates it as potentially threatening entity. Although, Salmonella strains isolated from vegetables in the study vary in their biochemical and antibiotic susceptibility pattern as indicated by the clusters, the presence of virulence genes supports the potentiality of these isolates to cause human infections.

In conclusion, the present study provides considerable insight to level of contamination of fresh raw vegetables with Salmonella enterica which are routinely being consumed in daily households as well as sold to the restaurants. The high risk of illness associated with its raw consumption has been assessed and correlated with the virulence factors present in the isolates of Salmonella enterica. The high plate count of Salmonella enterica in seven vegetables can be marked for its well establishment in local environment. Presence of the target genes in indigenous isolates from this study is the evident of well-established salmonella pathogenicity islands (SPI). The prevalence of virulence genes and their expression in-vivo may contribute to emerging risks of illness. By understanding and determining these critical control points, contamination intervention strategy can be implemented stringently.

\section{References}

Abadias, M., Usall, J., Anguera, M., Solsona, C., and Vinas, I. 2008. Microbiological quality of fresh, minimally-processed fruit and vegetables, and sprouts from retail establishments. Int. J. Food Microbiol. 123: 121-129.

Adeshina, G.O., Jibo, S.D., and Agu, V.E. 2011. Antibacterial susceptibility pattern of pathogenic bacteria isolates from vegetable salad sold in restaurants in Zaria, Nigeria. J. Microbiol. Res. 2:5- 
11.

Amini, K., Zahraei, T.S., Gholamreza, N., Reza, R., Javid, A., and Shahrnaz, B.A. 2010. Molecular detection of invA and spv virulence genes in Salmonella enteritidis isolated from human and animals in Iran. Afr. J. Microbiol. Res. 4: 2202-2210.

Andrews, W.H., and Hammack, T.S. 2008. Salmonella. In: Bacteriological Analytical Manual Revision (Eds.) A. Gaithersburg. 5th edn. U.S. Food and Drug Administration, AOAC International. Pp.8.

Aycicek, H., Oguz, U., and Karci, K. 2006. Determination of total aerobic and indicator bacteria on some raw eaten vegetables from wholesalers in Ankara, Turkey. Int. J. Hyg. Environ. Health 209:197-201.

Bajaj, V., Lucas, R. L., Hwang,C., and Lee, C.A. 2008. Co-ordinate regulation of Salmonella typhimurium invasion genes by environmental and regulatory factors is mediated by control of hilA expression. Mol. Microbiol. 22:703714.

Cardamone, C., Aleo, A., Mammina, C., Oliveri, G., and Di Noto, A.M. 2015. Assessment of the microbiological quality of fresh produce on sale in Sicily, Italy: preliminary results. J. Biol. Res. (Thessalon) 22:3.

Choudhary, A., Gopalakrishnan, R., Nambi, P.S., Ramasubramanian, V., Ghafur, K.A., Thirunarayan, M.A. 2013. Antimicrobial susceptibility of Salmonella enterica serovars in a tertiary care hospital in southern India. Ind J Med Res 137:800.

Cummings, K., Barrett, E., Mohle-Boetani, J.C., Brooks, J.T., Farrar, J., Hunt, T., Fiore, A., Komatsu, K., Werner, S.B., and Slutsker, L. 2001. A multistate outbreak of Salmonella enterica serotype Baildon associated with domestic raw tomatoes. Emerg. Infect. Dis. 7:1046-1048.

De Oliveira, M.A., De Souza, V.M., Bergamini, A.M.M., and De Martinis, E.C.P. 2011. Microbiological quality of ready-to-eat minimally processed vegetables consumed in Brazil. Food Control 22:1400-1403.

Delbeke, S., Ceuppens, S., Jacxsens, L., and Uyttendaele, M. 2015. Survival of Salmonella and Escherichia coli O157:H7 on strawberries, basil, and other leafy greens during storage. J. Food Prot 78:652-660.

El Allaoui, A., Rhazi, F.F., Essahale, A., Bouchrif, B., Karraouan, B., and Ameur, N. 2013. Characterization of antimicrobial susceptibility, virulence genes and identification by $16 \mathrm{~S}$ ribosomal RNA gene sequencing of Salmonella serovars isolated from turkey meat in Meknes, Morocco. Int. J. Microbiol. Immunol. Res. 1:68-79.

Galán, J.E., and Curtiss, R.III. 1990. Expression of Salmonella typhimurium genes required for invasion is regulated by changes in DNA supercoiling. Infect. Immunol. 58:1879-1885.

Galán, J.E., and Zhou, D. 2000. Striking a balance: modulation of the actin cytoskeleton by Salmonella. Proceedings of National Acad. Sci. 97:8754-8761.

García-Villanova, B., Galvez-Vargas, R., and García-Villanova, $\quad$ R. 1987. Contamination on fresh vegetables during cultivation and marketing. Int. J. Food Microbiol. 4:285-291.

Gole, V.C., Chousalkar, K.K., and Roberts, J.R. 2013. Survey of Enterobacteriaceae contamination of table eggs collected from layer flocks in Australia. Int. J. Food Microbiol. 164:161-165.

Gopinath, S., Carden, S., and Monack, D. 2012. Shedding Light on Salmonella 
Carriers, Trends Microbiol. 20:320-327.

Guo, X., Chen, J., Brackett, R.E., and Beuchat, L.R. 2001. Survival of Salmonellae on and in tomato plants from the time of inoculation at flowering and early stages of fruit development through fruit ripening. Appl. Environ. Microbiol. 67:47604764.

Hasan, R., Zafar, A., Abbas, Z., Mahraj, V., Malik, F., and Zaidi, 2008. Antibiotic resistance among Salmonella enterica serovars Typhi and Paratyphi A in Pakistan (2001-2006). J. Infect. Dev. Ctries. 2:289-294.

Hersh, D., Monack, D.M., Smith, M.R., Ghori, N., Falkow, S., and Zychlinsky, A. 1999. The Salmonella invasin SipB induces macrophage apoptosis by binding to caspase-1. Proc. Natl. Acad. Sci. U.S.A. 96:2396-2401.

Jeddi, M.Z., Masud, Y., Gorji, M.E., Noori, N., Pourmand, M.R., and Khaniki, G.R.J. 2014. Microbial Evaluation of Fresh, Minimally-processed Vegetables and Bagged Sprouts from Chain Supermarkets. J. Health Popul. Nutr. 32:391-399.

Karmi, M. 2013. Detection of Virulence Gene (inva) in Salmonella Isolated from Meat and Poultry Products. Int. J. Gen. 3:0712.

Lilic, M., Galkin, V.E., Orlova, A., VanLoock, M.S., Egelman, E.H., and Stebbins, C.E. 2003. Salmonella SipA polymerizes actin by stapling filaments with nonglobular protein arms. Science. 301:918-1921.

Najwa, M.S., Rukayadi, Y., Ubong, A., Loo, Y.Y., Chang, W.S., Lye, Y.L., Thung, T.Y., Aimi, S.A., Malcolm, T.T.H., Goh, S.G., Kuan, C.H., Yoshitsugu, N., Nishibuchi, M., and Son, R. 2015. Quantifiation and antibiotic susceptibility of Salmonella spp., Salmonella enteritidis and Salmonella typhimurium in raw vegetables (ulam) Int. J. Food Res. 22:1761-1769.

Ochiai, R.L., Acosta, C.J., DanovaroHolliday, M.C., Baiqing, D., Bhattacharya, S.K., Agtini, M.D., Bhutta, Z.A., Cahn, D. G., Ali, M., Shin, S., and Wain, J. 2008. A study of typhoid fever in five Asian countries: disease burden and implications for controls. Bulletin of the World Health Organization 86:260-268.

Popoff, M.Y., and Le Minor, L.E. 2005. Salmonella. In: Bergey's Manual of Systematics of Archaea and Bacteria.

Potnis, N., Colee, J., Jones, J.B., and Barak, J.D. 2015. Plant Pathogen-Induced Water-Soaking Promotes Salmonella enterica Growth on Tomato Leaves. Appl. Environ. Microbiol. 81:8126-8134.

Rowlands, R.E.G., Ristori, C.A., Ikuno, A.A., Barbosa, M.L., Jakabi, M., and Franco, B.D.G.D.M. 2014. Prevalence of drug resistance and virulence features in Salmonella spp. isolated from foods associated or not with salmonellosis in Brazil. Rev. Inst. Med. Trop. São. Paulo. 56:461-467.

Saddik, M.F., El-sherbeeny, M.R., and Bryan, F.L. 1985. Microbiological profiles of Egyptian raw vegetables and salads. J. Food Prot. 48:883-886.

Salleh, N.A., Rusul, G., Hassan, Z., Reezal, A., Isa, S.H., Nishibuchi, M., and Radu, S. 2003. Incidence of Salmonella spp. in raw vegetables in Selangor, Malaysia. Food Control. 14:475-479.

Sant'Ana, A., Barbosa, M., Destro, M., Landgraf, M., and Franco, B. 2012. Growth Potential of Salmonella spp. and Listeria monocytogenes in Nine Types of Ready-To-Eat Vegetables Stored at Variable Temperature Conditions during Shelf-Life. Int. J. Food Microbiol. 157:52-58.

Scallan, E., Hoekstra, R.M., Angulo, F.J., Tauxe, R.V., Widdowso, M.A., Roy, 
S.L., Jones, J.L., Griffin, P.M. 2011. Food- borne illnesses acquired in the United States-Major pathogens. Emerg. Infect. Dis. 17:7-15.

Schleker, S., Kshirsagar, M., and KleinSeetharaman, J. 2015. Comparing human-Salmonella with plantSalmonella protein-protein interaction predictions. Front Microbiol. 6:1-10.

Seo, Y.H., Jang, J.H., and Moon, K. D. 2010. Microbial evaluation of minimally processed vegetables and sprouts produced in Seoul, Korea. Food Sci. Biotechnol. 19:1283-1288.

Sood, S., Kapil, A., Das, B., Jain, Y., and Kabra, S.K. 1999. Re-emergence of chloramphenicol-sensitive

Salmonella typhi. Lancet. 353:12411242.

Viswanathan, P., and Kaur, R. 2001. Prevalence and growth of pathogens on salad vegetables, fruits and sprouts. Int. J. Hyg. Environ. Health 203:205-213.

\section{How to cite this article:}

Sood, B., P. Sahota and Hunjan, M. 2017. Fresh Farm Vegetables as a Source of Virulent Drug Resistant Salmonella Enterica. Int.J.Curr.Microbiol.App.Sci. 6(8): 3233-3245. doi: https://doi.org/10.20546/ijcmas.2017.608.386 